\title{
【原 著】
}

\section{クマザサ含有成分による CCL2 依存性のヒトサイトメガロウイ ルス増殖抑制効果}

\section{Inhibition of Human Cytomegalovirus Replication by Compound Derivative from Sasa albomarginata is Associated with CCL2/ CCR2 Interaction}

\author{
赤井佑三子 ${ }^{1}$, 茂木香保里 ${ }^{1}$, 定成秀貴 ${ }^{1}$, 武本眞清 ${ }^{1}$, 松原京子 $^{1}$, \\ 大黒 徹 ${ }^{1}$, 土田裕三 ${ }^{2}$, 桜井大輔 ${ }^{2}$, 村山次哉 ${ }^{1,}$ \\ Yumiko AKAI ${ }^{1}$, Kaori MOGI ${ }^{1}$, Hidetaka SADANARI ${ }^{1}$, Masaya TAKEMOTO', \\ Keiko MATSUBARA', Tohru DAIKOKU', Yuuzo TSUCHIDA ${ }^{2}$, \\ Daisuke SAKURAI ${ }^{2}$, Tsugiya MURAYAMA ${ }^{1, *}$ \\ ${ }^{1}$ 北陸大学薬学部生命薬学講座 \\ 2 株式会社鳳凰堂
}

【要 旨】

我々はこれまでに, イネ科植物クマザサの含 有成分の一つである tricin が, ヒトサイトメ ガロウイルス (human cytomegalovirus: HCMV) に対して抗ウイルス効果を示すこ とを明らかにして来た. 本研究では, 既存の 抗炎症薬であり CCR2 アンタゴニストであ る germanium 化合物を用いて, tricin と の抗 HCMV 作用を比較検討することでその 作用機序を明確にすることを目的とした. その結果, HCMV 感染により増加した CCL2 と CCR2 の遺伝子発現とタンパク質 発現および HCMV 増殖は, germanium 化 合物処理により濃度依存的に抑制された。 ま た tricin 処理では, germanium 化合物に 比較してより強い抑制効果が観察され, 約 1/100 の濃度で有意に抑制されることが明 らかになった。

これらの結果から，既存の抗炎症薬・ germanium 化合物より強力な CCL2 発現 抑制作用や抗 HCMV 作用をもつ tricin は,
これまでの抗 HCMV 薬には見られない新た な作用機序を持つ抗炎症性 HCMV 治療薬の 候補となる可能性が示唆された.

【キーワード】

ヒトサイトメガロウイルス, トリシン, CCL2, CCR2, プロパゲルマニューム, 抗炎症薬

はじめに

ヒトサイトメガロウイルス (human cytomegalovirus: HCMV) は，ヘルペスウイルス科の $\beta$ ヘルペスウイルス 亜科に属し，二本鎖 DNA ゲノムを持つウイルスである. 我国では 70 〜 90 \%のヒトが幼少期に感染するが，ほと んどが不顕性感染の形で生涯体内に潜伏感染し続け, 臓 器移植患者や抗がん剂治療患者などの易感染宿主では潜 伏 HCMV が再燃し，間質性肺炎・網膜炎・大腸炎などの 重篤な日和見感染症を引き起こし，失明や死亡の原因と なることが知られている ${ }^{1-3)}$ 。しかし，近年若年層の抗体 保有率が $60 \sim 70 \%$ に低下しており，妊婦が初感染する とウイルスが経胎盤的に胎児に感染し，難聴・精神運動 発達遅滞等の先天性 HCMV 感染症を引き起こすことが

受理日：2017 年 8 月 9 日

* \% 920-1181 石川県金沢市金川町ホ- 3 番地

Tel : 076-229-6223 Fax: 076-229-2781 E-mail : t-murayama@hokuriku-u.ac.jp 
問題となっており ${ }^{3-5)}$ ，その頻度は全出生児 300 人当り 1 人と高く，早期対策が望まれている ${ }^{5,6)}$ 。また, HCMVが 炎症性ケモカインのCCL2 (CC motif chemokine ligand 2) を発現誘導し，血管内皮細胞に慢性的な炎症を起こすこと で動脈硬化症の誘発や促進につながるとの報告もある ${ }^{7-10)}$. しかし，その詳細は明らかとなっていない。現在，このよ うな HCMV 感染防御のための有効なワクチンはなく, 日 本で認可されている抗 HCMV 薬として，ガンシクロビル， バルガンシクロビル，ホスカルネットがあり，これらの薬 剤の作用点はいずれもウイルス DNA ポリメラーゼ阻害に よる HCMV の増殖抑制である ${ }^{11,12)}$ 。最近，これらの長期 投与による薬剤耐性化や骨髄抑制等の副作用が問題となつ ており，新たな作用機序を持つ抗 HCMV 薬の早急な出現 が求められている.

我々はこれまでに種々の生薬成分を用いた抗ウイルス 薬の検索を行っており, クマザサの熱水抽出物とそこか ら分離・精製された 5 つの既知成分が, 抗 HCMV 活性 を示すことを報告している ${ }^{13,14)}$. クマザサ（学名：Sasa albomarginata) は, イネ科の一種で，日本やロシアの千 島列島の一部に自生し，日本をはじめアジア諸国などで は昔から伝統的な民間薬，食べ物を包む材料等として用 いられてきた。また，クマザサの水溶性分画から得られた 成分は，抗酸化作用，抗腫瘍作用，抗炎症作用，抗ウイル ス作用などの生理活性を持つことが知られている ${ }^{15-17)}$.さ らにこの 5 つの既知成分の中から，フラボン誘導体であ る tricin (4',5,7-trihydroxy-3',5'-dimethoxy flavone) が 最も強い抗 HCMV 活性を示すことを報告した ${ }^{14)}$. Tricin による抗 HCMV 作用機序の一端として COX-2 (cyclo oxygenase-2), CXCL11 (CXC motif chemokine ligand 11), CCL2 等が関係していることも報告してきた ${ }^{14,18,19)}$. CCL2 は内皮細胞や腫瘍細胞，単球などで恒常的に発現， あるいは種々の刺激応答によって産生される。産生された CCL2 は CCR2 に結合し, 単球走化作用, 白血球遊走作用, サイトカイン産生を制御することが知られている ${ }^{20,21)}$ 。ま た，CCL2 遺伝子ノックダウン細胞では HCMV の増殖が 抑制され，ここに CCL2 リガンドを加えることにより抑制 された増殖が回復することも明らかにしてきた ${ }^{22)}$ 。このよ うに，CCL2 依存性の抗 HCMV 効果が明らかにされてい るが， tricinの CCL2 産生抑制作用の詳細はわかっていな い. そこで本研究では, 既存の抗炎症薬である CCR2 アン タゴニストの germanium 化合物と tricin による抗 HCMV 作用を比較検討し, HCMV 増殖に対する CCL2 の相互関 係を明確にすると共に, tricin による抗 HCMV 効果の作 用機序を検討することとした。

\section{材料・方法}

\section{1. 培地}

接着細胞培養用の培地として，8\%の牛胎児血清 (FCS :
GIBCO, USA), Penicillin (100 units/mL : ナカライテス ク, 京都), Streptomycin (100 $\mu \mathrm{g} / \mathrm{mL}$ : ナカライテスク), L-glutamine（0.6 mg/mL : ナカライテスク）を添加した Dulbecco's Modified Eagle Medium（DMEM : 日水製薬， 東京）を用いた。浮遊細胞培養用の培地として 8 \% FCS 含有 RPMI-1640 培地（Wako，大阪）を用いた。

\section{2. 細胞培養}

HCMV 感染には，ヒト胎児肺線維芽細胞 (Human embryonic lung fibroblast : HEL) を用いた。 HEL 細胞を 目的に応じて組織培養用器具 (24 wells プレート, T25 フ ラスコ, T75 フラスコ, $9.6 \mathrm{~cm}^{2}$ ディッシュ : ベクトン・ ディッキンソン, 東京）に播種し， 8 \% FCS 含有 DMEM 培地を加え， $37^{\circ} \mathrm{C}, 5 \% \mathrm{CO}_{2}$ の条件下で培養した。

細胞遊走性試験に用いたヒト単球性白血病由来細胞株 THP-1 は, 8 \% FCS 含有 RPMI-1640 培地で培養した。

\section{3. ウイルス}

ウイルスは，HCMV の実験室継代株である Towne 株を 用いた ${ }^{23)}$. HEL 細胞にウイルスを感染多重度 $(\mathrm{MOI})=1$ として 1 時間吸着感染後, 2 \% FCS 含有 DMEM 培地で培 養した。ウイルスが十分に増殖する 7 日目頃の培養上清を 回収し， $1,200 \times g$ で 15 分間遠心後，上清をウイルス液 として液体窒素中に保存し，用時溶解して実験に供した。 ウイルス量の測定はプラークアッセイ法 ${ }^{24)}$ (詳細は後述) にて行った。 Mock感染では, ウイルス液の代わりに培養 液を用いた。

\section{4. 試薬}

Tricin は有機合成されたものを用い，構造式を図 1 に示 した. Germanium 化合物であるビス [2 - カルボキシエチ ルゲルマニウム (IV) ] セスキオキシド (3,3'-(1,3-Dioxo1,3-digermoxanediyl)dipropionic acid) ${ }^{25,26)}$ は，東京化 成工業（東京）より購入し，構造式を図 2 に示した。 DMSO，トリプシン - エチレンジアミン四酢酸（EDTA） 溶液はナカライテスク（京都）より，イソプロパノール， エ夕ノール，炭酸水素ナトリウムは和光純薬工業（大阪） より, リン酸緩衝液 (PBS) は, 日水製薬（東京）より購 大した。<smiles>COc1cc(-c2cc(=O)c3c(O)cc(O)cc3o2)cc(OC)c1O</smiles>

図 1 Tricin (4',5,7-trihydroxy-3',5'-dimethoxyflavone) の構造式 


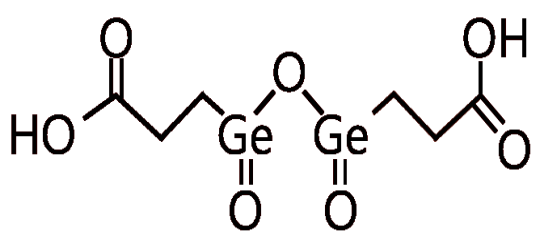

図 2 Germanium 化合物 (3,3'-(1,3-Dioxo-1, 3-digermoxanediyl)dipropionic acid) の構造式

\section{Tricin または germanium 化合物による抗ウイルス効果 の測定}

$9.6 \mathrm{~cm}^{2}$ シャーレで単一層の HEL 細胞に HCMVを MOI = 1 で感染させ, DMSO で 10 倍に段階希釈した tricin $(0.1,1,10 \mu \mathrm{M})$ ，またはPBS で 3 倍に段階希釈した germanium 化合物 $(0.3,1,3,10 \mu \mathrm{M})$ を加え 6 日間培養 後，培養上清中の HCMV 粒子数をプラーク法により定量 した。プラーク法は，24 wells プレートで単一層の HEL 細胞に，10 倍段階希釈した培養上清を感染後，2％ FCS 及び $0.4 \%$ 寒天含有 DMEM 培地を重層し培養した。培養 6 日後, 出現したプラークの数を顕微鏡下で数え, ウイル ス量を測定した。

\section{6. real-time RT-PCR 法による解析}

6-1. HCMV 感染細胞からの total RNA の抽出

$9.6 \mathrm{~cm}^{2}$ シャーレで単一層の HEL 細胞に, HCMVを MOI = 1 で感染後, tricin またはgermanium化合物を加え, 72 時間培養後 PBS で細胞を洗浄後, ISOGEN II (ニッポ ンジーン,富山)を $0.5 \mathrm{~mL}$ 加え細胞を溶解した，さらに 0.2
$\mathrm{mL}$ の RNase free 水を加え, 15 秒間混合し, 10 分間静置 後 $15,000 \times g$ で 15 分間遠心し, 上清に $0.5 \mathrm{~mL}$ のイソプ ロパノールを加え転倒混和した後, 室温で 10 分間静置し た. $9,500 \times g$ で 10 分間遠心し, 沈殿に $0.5 \mathrm{~mL}$ の $75 \%$ エタノールを加え， $7,000 \times g$ で 3 分間遠心した。これを 2 回繰り返し, 上清を捨て風乾し, RNase free 水 $20 \mu \mathrm{L}$ で溶解し total RNA 溶液とした. Total RNA 量は, Nano Photometer（アズワン，大阪）を用い算出した。尚，得 られた total RNA 中に DNA 混入のない事を PCR 反応に て確認している.

\section{6-2. real-time RT-PCR 法}

得られた total RNAからの cDNA 合成は, Revertra Ace ${ }^{\circledR}$ qPCR RT Master Mix (TOYOBO, 大阪)を用いて行っ た。逆転写反応は, iCycler（Bio-Rad Laboratories，東京） を用い, $37^{\circ} \mathrm{C} 15$ 分, $50^{\circ} \mathrm{C} 5$ 分の反応を行った後, $98^{\circ} \mathrm{C}$ 5 分処理し逆転写酵素を失活させた。合成した cDNAの 5 $\mu \mathrm{L}$ を鋳型として, GoTaq ${ }^{\circledR}$ qPCR Master Mix (Promega, 東京) を $15 \mu \mathrm{L}$, Primer Forward $(10 \mathrm{pmol} / \mu \mathrm{L})$ と Primer Reverse (10 pmol $/ \mu \mathrm{L})$ を各 $1 \mu \mathrm{L}$ 加え, PCR プレー トに分注した。 PCR反応は Mini Opticon real-time RTPCR (Bio-Rad Laboratories) を用い，95 $\mathrm{C} 10$ 秒，アニー リング温度で 20 秒， $72^{\circ} \mathrm{C} 20$ 秒を 1 サイクルとし，これ を 40 サイクル行った。目的の遺伝子の発現量は, $\beta$ - actin の発現量で標準化し, tricin 未処理, germanium 化合物未 処理の場合を $100 \%$ として比較した. PCR 反応に用いた 各プライマーは，表 1 に示した文献を参考に設計した。こ れらのプライマーの合成は, 株式会社グライナージャパン （東京）に依頼した.

表 1 real-time RT-PCR 法に用いたプライマー配列

\begin{tabular}{|c|c|c|c|}
\hline プライマー & アニ & $\begin{array}{l}\text { ニーリング } \\
\text { 温度 }\left({ }^{\circ} \mathrm{C}\right)\end{array}$ & 参考文献 \\
\hline Actin for. & 5’-ATC ATG TTT GAG ACC TTC AAC-3’ & 注 1 & 30) \\
\hline Actin rev. & 5'-CAG GAA GGA AGG CTG GAA GAG-3' & & \\
\hline CCL-2 for. & 5'ATT CCC CAA GGG CTC GCT C-3' & 54.0 & $31)$ \\
\hline CCL-2 rev. & 5'-ACT TGC TGC TGG TGA TTC TTC-3' & & \\
\hline CCR-2 for. & 5'-GAC CAG GAA AGA ATG TGA AAG TGA-3' & 57.7 & $32)$ \\
\hline CCR-2 rev. & 5'-GCT CTG CCA ATT GAC TTT CCT T-3' & & \\
\hline IE-1 for. & 5'TAT ACC CAG ACG GAA GAG AAA TTC-3' & 53.1 & 注 2 \\
\hline IE-1 rev. & 5’-CTG CAG TGC ACC CCC CAA CTT G-3' & & \\
\hline UL54 for. & 5'TTG CGG GTT CGG TGG TTA-3' & 55.5 & $33)$ \\
\hline UL54 rev. & 5'-CGG CCA TAG TGT TGA GCT TAT AGT T-3' & & \\
\hline CCR-3 for. & 5'-CTG CTA CAC AGG AAT CAT CAA AAC-3' & 57.7 & $34)$ \\
\hline CCR-3 rev. & 5’-GTT CTT TCC AGC TTC TCA CTA GGA AG-3’ & & \\
\hline CCR-5 for. & 5'-CTG ACA TCT ACC TGC TCA ACC-3' & 57.7 & $32)$ \\
\hline CCR-5 rev. & 5'-GAA GAT TCC AGA GAA GAA GCC-3' & & \\
\hline IL-1 $\beta$ for. & 5'-CAC GAT GCA CCT GTA CGA TCA-3' & 54.0 & $35)$ \\
\hline IL-1 $\beta$ rev. & 5’-GTT GCT CCA TAT CCT GTC CCT-3' & & \\
\hline
\end{tabular}

注 1 : Actinのアニーリングは各遺伝子と同一の温度で行った。

注 2 : IE1 遺伝子領域のプライマーは, HCMV Towne 株の塩基配列をもとに当研究室で設計した。このプラ イマーを用い，増幅反応の特異性を融解曲線分析により確認したところ，目的のピークが 1 つだけ生 じていること，また PCR 産物を電気泳動することにより目的の長さの産物が生じていることを確認後, 使用した。 


\section{7. 蛍光マイクロビーズアレイによる CCL2 定量}

培養上清中の CCL2 量を, LEGENDplex Human Proinflammatory Chemokine Panel (BioLegend, CA, USA) を用いて定量した。培養上清 $25 \mu \mathrm{L}$ をメーカーのイ ンストラクションに記載された方法に従い抗体結合ビーズ と抗原抗体反応後， streptavidin-phycoerythrin で蛍光標 識し, BD FACS Calibur HG (BD Biosciences, CA, USA) により蛍光強度の測定を行った。得られた FACS のデータ をLEGENDplex Data Analysis Softwareに取り込み, サ ンプルと同時に準備した標準試料から作成した検量線上に プロットして CCL2 濃度を決定した。

\section{8. ケモタキシスアッセイ（細胞遊走性試験）}

THP-1 細胞を， $10^{6}$ 個 $/ \mathrm{mL}$ となるように chemotaxis buffer に懸濁した。96ウェルプレートに分注した培養上 清 $100 \mu \mathrm{L}$ の上に，ケモタキセル 96 (KURABO，大阪） を被せ，ケモタキセル 96 内に上述の THP-1 細胞懸濁液 $60 \mu \mathrm{L}$ を入れ， $37^{\circ} \mathrm{C} て ゙ 2$ 時間培養した。培養後ケモ夕キセ ル 96 を取り外し，血球計算板を用いて下層の培養上清に 遊走した THP-1 細胞数を測定した。

\section{9. 統計学的処理}

各測定值は，3 回の実験結果の平均值 \pm 標準偏差で示 した。統計学的処理が必要な実験は, 独立した 2 群の差 の検定は Student's $t$-test で，多群の差の検定には TukeyKramer 法を用いて有意差検定を行った。特に TukeyKramer 法による多重比較検定では，Statcel 4 のソフトウ エア（オーエムエス出版，埼玉県所沢市）を用いて行った。 $\mathrm{p}$ 值 $0.05 （ 5 \%$ で有意）および $0.01 （ 1 \%$ で有意）を統
計学的有意水準とした。

\section{結 果}

1. CCL2 及び CCR2 遺伝子発現に対する germanium 化 合物または tricin 処理の影響

HCMV 感染刺激により増強された CCL2 遺伝子発現量 は, germanium 処理により $0.3 \mu \mathrm{M}$ で約 $30 \%, 10 \mu \mathrm{M}$ では約 $75 \%$ 抑制された。一方， tricin 処理では $0.1 \mu \mathrm{M}$ で約 $70 \%, 10 \mu \mathrm{M}$ では対照の非感染細胞のレベルまで 完全に抑制された（図 3-A), germanium 化合物 $10 \mu \mathrm{M}$ と tricin $0.1 \mu \mathrm{M}$ がほぼ類似の抑制効果を示したことか ら, tricin 処理の方が germanium 処理に比較して, 約 100 倍強い抑制効果を示したことが明らかとなった。図 3-B に示すように CCR2 の遺伝子発現量は, tricin 処理に より $0.1 \mu \mathrm{M}$ で約 $25 \% ， 10 \mu \mathrm{M}$ では約 $70 \%$ 抑制された。 germanium 処理では $0.3 \mu \mathrm{M}$ で約 $50 \%, 10 \mu \mathrm{M}$ では対照 のレベルまで完全に抑制された。このことから，CCR2 遺 伝子発現量に対する影響は, tricin に比較して germanium 化合物の方が，より強い抑制効果があることが示された.

\section{CCL2 タンパク質産生に対する germanium 化合物また} は tricin 処理の影響

CCL2 タンパク質産生に対する両薬物の影響を調べる ため，培養上清中に産生された CCL2 量を蛍光マイク ロビーズアレイ法により定量比較した。図 4 に示すよ うに, HCMV 感染刺激により産生増強された CCL2 は, germanium, tricin 処理両方共に有意に抑制されたが, tricin 処理群では非感染細胞のレベル以下まで強く抑制さ れた。
A
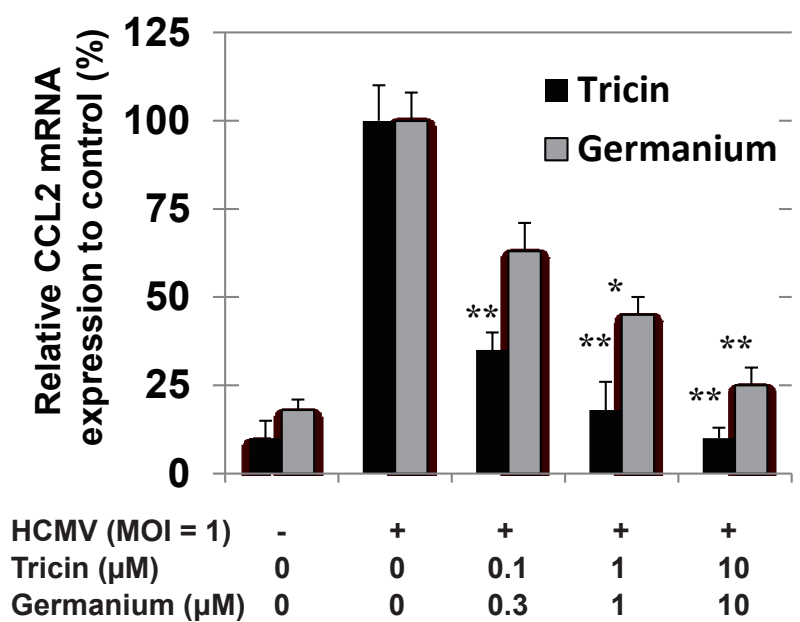

B

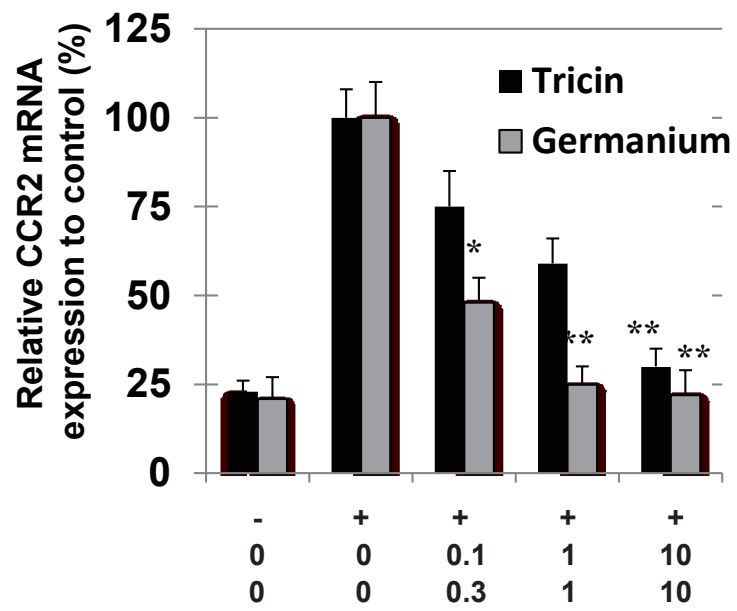

図 3 HCMV 感染細胞における CCL2 及び CCR2 遺伝子発現に対する germanium 化合物または tricin 処理の影響 HEL 細胞に HCMV を MOI= 1 で感染後，各濃度の germanium 化合物または tricin 処理を行い，72 時間培養後，total RNA を抽出し， CCL2（A）及び CCR2（B）遺伝子発現量を real-time RT-PCR 法を用いて解析した。CCL2 及び CCR2 遺伝子の発現量は， $\beta$-actinの 発現量で標準化し，各薬物未処理の HCMV 感染細胞を $100 \%$ として比較した。

統計解析は薬物未処理感染細胞と比較し，Tukey-Kramer 法で有意差検定を行った。 $\left({ }^{*} P<0.05 ;{ }^{* *} P<0.01\right)$ 


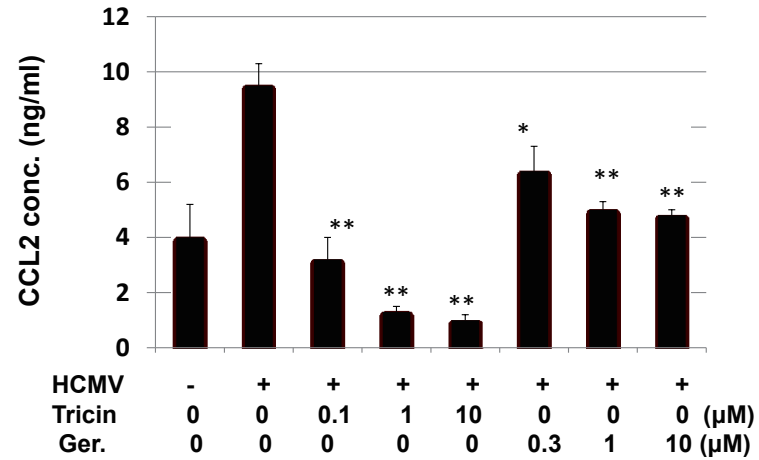

図 4 HCMV 感染細胞培養上清中の CCL2 産生に対する germanium 化合物または tricin 処理の影響

HEL 細胞に HCMV を MOI= 1 で感染後, 各濃度の germanium 化合物または tricin 処理を行い，72 時間培養後，培養上清中に 産生された CCL2 量を蛍光マイクロビーズアレイ法により定量 した.

統計解析は薬物未処理感染細胞と比較し, Tukey-Kramer 法で 有意差検定を行った。 $\left({ }^{*} P<0.05 ;{ }^{* *} P<0.01\right)$

3. HCMV 特異的 IE 1, UL54 遺伝子発現に対する germanium 化合物または tricin 処理の影響

Tricin 処理の場合，図 5-A に示すように IE1，UL54 両 遺伝子発現量共に, $0.1 \mu \mathrm{M}$ で約 $40 \%, 10 \mu \mathrm{M}$ では約 70 $\%$ と濃度に依存して有意に抑制された。一方，図 5-B に示 すように germanium 処理による各遺伝子発現量は, 濃度 依存的な抑制傾向が見られたが，10 $\mathrm{\mu M}$ でも約 $50 \%$ しか 抑制されず，その強度は tricinの約 $1 / 100$ 程度であった。

\section{HCMV 増殖に対する germanium 化合物または tricin 処理の影響}

感染 6 日後の感染性 HCMV 量は，tricin 処理により抑
制され，0.1 $\mu \mathrm{M}$ で約 $60 \%, 10 \mu \mathrm{M}$ では約 $90 \%$ と濃度 依存的な抑制効果を示した（図 6). germanium 化合物で も濃度依存的な HCMV 増殖抑制効果がみられたが， tricin に比較するとその抑制効果は弱く, 約 $1 / 100$ 程度であった。

\section{5. 細胞遊走能に対する germanium 化合物または tricin 処 理の影響}

CCL2 は単球遊走作用があることから, 単球系細胞株 THP-1 を用いて細胞遊走性試験を行った。図 7 に示すよ うに, HCMV 感染により増加した遊走細胞数は, tricin 処理により有意に抑制された。この結果は，図 4 で示さ れた CCL2 産生の結果と同様であった。しかしながら, germanium 化合物処理では，わずかな遊走抑制しか観察 されなかった。

\section{考 察}

我々は，生薬を中心とした代替医療薬の中から抗ウイル ス活性を持つ成分の検索を行っており，イネ科植物クマザ サの含有成分の一つである tricin が最も強い抗 HCMV 効 果を示すこと ${ }^{13,14)}$, その作用機序として, 炎症性誘導因 子である COX-2 やケモカイン CXCL11 が関与しているこ とを明らかにしてきた ${ }^{14,18)}$ 。また最近，HCMV 感染によ り CCL2 の遺伝子発現およびタンパク質発現共に増強さ れ，それが tricinによって抑制されること，また CCL2 遺 伝子ノックダウン細胞では HCMV の増殖が抑制され，そ こに CCL2 リガンドを加えることによりその抑制が回復 することも報告している ${ }^{19,22)}$ 。このように CCL2 依存性 の抗 HCMV 効果が明らかにされたが, tricin が CCL2 産 生抑制に対しどのように作用しているかは明らかとなっ
A

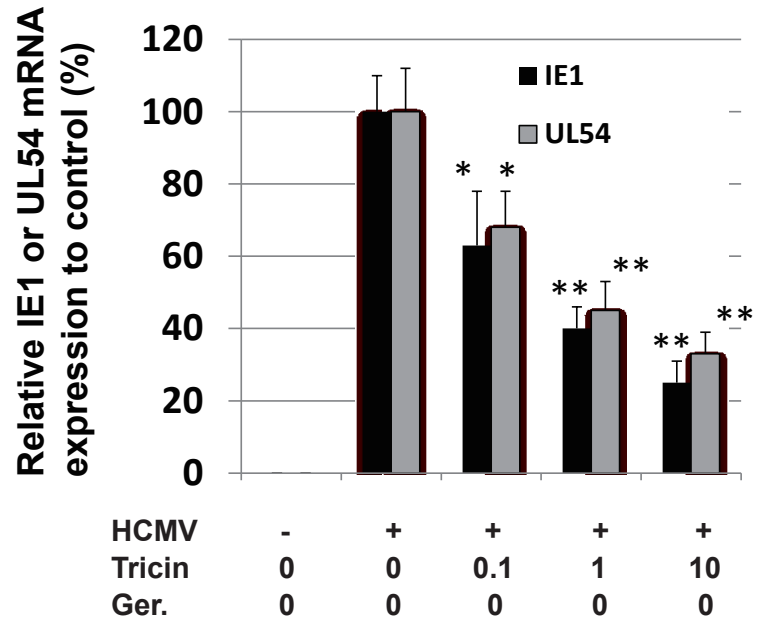

B

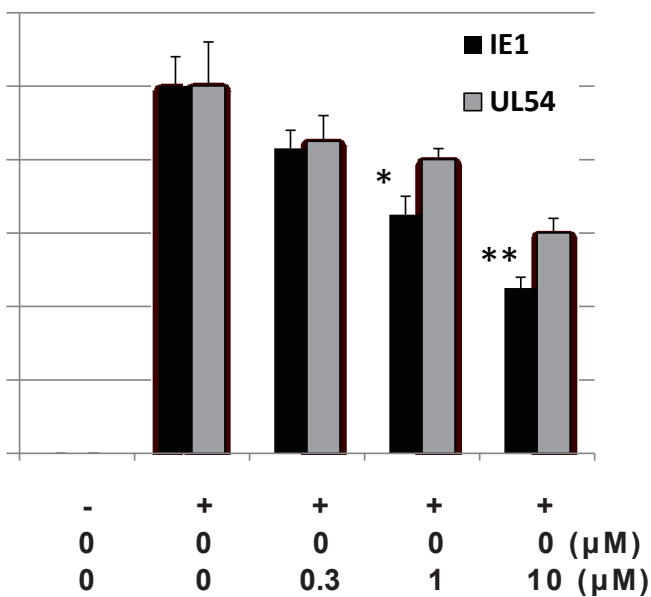

図 5 HCMV 感染後の IE1, UL54 遺伝子発現対する tricin 処理または germanium 処理の影響 HEL 細胞に HCMV を MOI= 1 で感染後, 各濃度の tricin (A) または germanium 処理（B）を行い, 72 時間培養後, total RNA を抽出し， HCMV 特異的 IE1，UL54 遺伝子の発現量を real-time RT-PCR 法を用いて解析した。IE1，UL54 遺伝子の発現量は， $\beta$-actinの発現 量で標準化し, germanium 化合物または tricin 未処理の HCMV 感染細胞を $100 \%$ として比較した。統計解析は薬物未処理感染細胞と 比較し, Tukey-Kramer 法で有意差検定を行った。 $\left({ }^{*} P<0.05 ;{ }^{* *} P<0.01\right)$ 


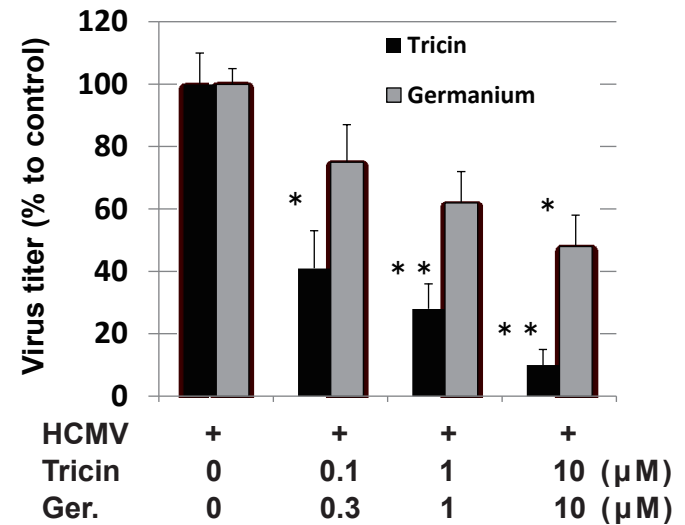

図 6 Germanium 化合物または tricin 処理による 抗 HCMV 効果の検討

HEL 細胞に HCMV $\mathrm{MOI}=1$ で感染後, 各濃度の germanium 化合物または tricin を添加した培地で 6 日間培養した。培養上 清中に産生された感染性 HCMV 数をプラーク法により測定し, 薬物未処理時の值を $100 \%$ としてそれぞれの抑制効果を比較し た。統計解析は薬物未処理感染細胞と比較し, Student's $t$-test で有意差検定を行った。 $\left({ }^{*} P<0.05 ;{ }^{* *} P<0.01\right)$

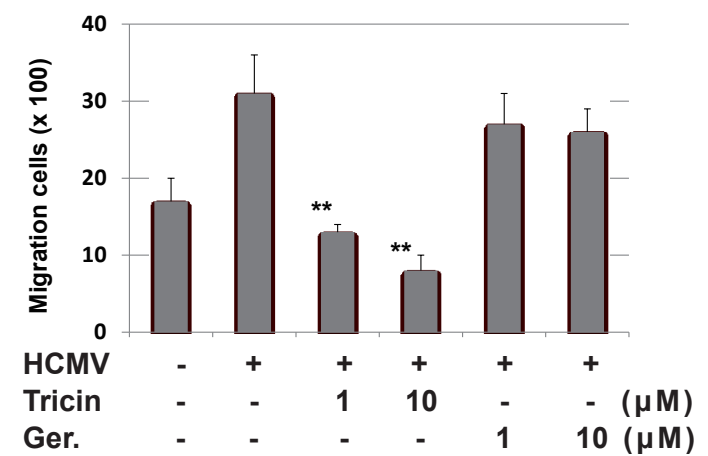

図 7 ケモタキシスアッセイ（細胞遊走性試験）

HEL 細胞に HCMV を MOI= 1 で感染後, $1,10 \mu \mathrm{M}$ tricin ま たは germanium 化合物処理を行い, 72 時間後の培養上清の THP-1 細胞に対する細胞遊走能を算定した。統計解析は薬物未 処理感染細胞と比較し, Tukey-Kramer 法で有意差検定を行っ た. $\left({ }^{* *} P<0.01\right)$

ていない。そこで，抗炎症薬として既に臨床応用されてい る CCR2 アンタゴニストの germanium 化合物を用いて, HCMV 増殖に対する CCL2 の相互関係を明確にすると共 に, tricin による抗 HCMV 効果の作用機序との比較検討 を行った。

最初に, HCMV 感染刺激により増強された CCL2 遺伝 子発現は両薬物により抑制されるが， tricin は germanium 化合物に比較して約 100 倍強い抑制効果を持つことが示 された（図 3)。また，CCL2 産生は，germanium 化合物 処理により非感染細胞のレベルまで抑制されたが， tricin 処理ではさらに強く抑制され，非感染細胞レベル以下まで 抑制された（図 4)。非感染 HEL 細胞で恒常的な CCL2 産 生が多い理由の一つとして, 培養液中の特に FCS 中に含 まれる未知の活性化因子（FCS の Lot 間や濃度差によっ
て CCL2 発現量に差のある事は確認しているが, 原因分 子は特定されていない）等による刺激の可能性が考えられ る事から, tricin はこれらの未知活性化因子による CCL2 産生をも抑制したと思われる。このような tricinによる CCL2 産生抑制機序としては, 細胞膜への付着・結合刺激 により何らかの細胞内シグナル伝達経路が活性化し, 結果 として CCL2 遺伝子発現が抑制されるような 1 つの機序 が予想される。一方, CCR2 遺伝子発現に対する影響は, germanium 化合物の方が tricin に比較して，より強い抑 制効果を示した（図 3-B)。 。た未発表データではあるが, germanium 化合物は，他のケモカイン受容体 CCR3 およ び CCR5 の遺伝子発現は抑制しないことを明らかにしてい る。この事から, germanium 化合物が CCR2 に特異的に 作用することにより細胞内シグナル伝達経路が働き, 最終 的に CCL2 遺伝子発現が抑制されるような 1 つの機序が考 えられる. CCL2 は HEL 細胞や腫瘍細胞, 内皮細胞, 単球 などで恒常的，あるいは種々の刺激応答によって産生され， 単球や好塩基球に発現する CCR2 に結合して遊走を引き起 こし, 単球においては接着因子の発現やサイトカインの産 生を制御していることが知られている ${ }^{20,21)}$ 。また, CCL2 が CCR2 に結合し，構造タンパク質の actin や tubulin を 再構成し, 遊走に適した細胞形態に変化させているとの報 告もあり ${ }^{27,28)}$, in Vivo ではマクロファージや単球の前駆 細胞が HCMV の潜伏感染細胞としてリザーバーとなって おり，遊走によりウイルスの拡散と再燃を引き起している 可能性がある. Tricin による CCL2 の発現・産生の抑制お よび単球遊走能の抑制は, これら潜伏ウイルスの拡散や再 燃をも抑制する可能性が充分に考えられる。

HCMV 特異的 IE1, UL54 遺伝子発現に対する検討では, tricinの方が germanium 化合物に比較してょり強い抑制 効果を示した（図 5)。さらに, HCMV の増殖抑制につい ては, germanium 化合物 $10 \mu \mathrm{M}$ と tricin $0.1 \mu \mathrm{M}$ が同等 の抑制効果を示したことから, tricin は germanium 化合 物に比較して, 約 100 倍強い HCMV 増殖抑制効果を持つ ことが示された (図 6). IE1 遺伝子は, HCMV 増殖過程 の初期段階に関わる前初期遺伝子, UL54 遺伝子はウイル ス DNA ポリメラーゼをコードする遺伝子であることから， tricin は少なくともこれらの遺伝子発現を抑制することで, その下流の遺伝子発現やタンパク質発現をカスケード的に 抑制し，強い HCMV 増殖抑制効果を示した可能性がある. また, tricin は CXCL11 やCCL5 等の複数のケモカイン 産生抑制能を持つことから, HCMV 増殖抑制効果がより 強力になった可能性も示唆される。Tricinの毒性に関して は, in vitro での HEL 細胞を用いた検討から IC50 が590〜

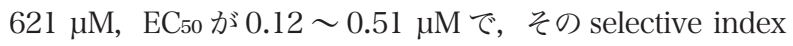

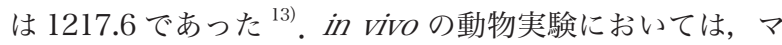
ウスへの経口投与で $2000 \mathrm{mg} / \mathrm{kg}$ 投与しても体重減少や臓 器異常は見られなかつた ${ }^{29)}$ 等から, tricinの安全性につい ても大きな問題はないと思われる。ささらに, tricin は GCV とは異なる作用機序を持ち, 既存の抗炎症薬より CCL2 産 
生抑制作用や抗 HCMV 作用も強いため, 新たな抗炎症性 HCMV 感染症治療薬として応用できる可能性が高いこと が示唆された。今後は HCMV 感染刺激による CCL2 発現 増強の作用機序や tricin 処理による遺伝子発現抑制の作用 機序について明らかにしていく必要がある.

\section{結 論}

HCMV 感染で増加した CCL2, CCR2, IE1, UL54 等の 遺伝子発現は, germanium 化合物処理により濃度依存的 に抑制されたが, tricin 処理による抑制は germanium 処 理に比較して, より強い効果が観察された。また, HCMV 増殖に対する効果は, 両薬物処理により共に濃度依存的に 抑制され，特に tricin では germanium の約 $1 / 100$ の濃度 で有意に抑制された。以上の事から， tricin は既存の抗炎 症薬より CCL2 産生抑制作用と抗 HCMV 作用が強く, こ れまでの抗 HCMV 薬にはない新たな抗炎症性 HCMV 治療 薬と成り得る可能性が示唆された。

\section{助成元}

本研究の助成元は, JSPS 科研費 (15K09587, 24591492), $2015 \sim 2016$ 年度北陸大学特別助成金，お よび第 30 回北國がん基金等の助成により遂行されたもの であり，心より謝意を表します。

\section{謝 辞}

本研究は, 北陸大学薬学部生命薬学講座生体防御薬学分 野で行われたものであり, 研究遂行にご協力いただいた多 くの学生諸氏に深謝致します.

\section{参考文献}

1) Ho M. Virus infections after transplantation in man. Brief review. Arch Virol. 1977; 55: 1-24.

2) Tanaka M, Sato Y, Sata T. [Pathology of herpesvirus infection]. Nihon Rinsho. 2006; 64 Suppl 3: 49-54.

3) Sissons JG, Carmichael AJ. Clinical aspects and management of cytomegalovirus infection. J Infect. 2002;44:78-83.

4) Fowler KB, Stagno S, Pass RF, et al. The outcome of congenital cytomegalovirus infection in relation to maternal antibody status. N Engl J Med. 1992; 326: 663-667.

5) Numazaki K. Congenital infection and HCMV. Nihon Rinsho. 2006; 64 Suppl 3: 496-499.

6) Koyano S, Inoue N, Oka A, et al. Screening for congenital cytomegalovirus infection using newborn urine samples collected on filter paper: feasibility and outcomes from a multicentre study. BMJ Open. 2011; 1: e000118.

7) Chen R, Xiong S, Yang Y, et al. The relationship between human cytomegalovirus infection and atherosclerosis development. Mol Cell Biochem. 2003; 249: 91-96.

8) Olofsson PS, Jatta K, Wagsater D, et al. The antiviral cytomegalovirus inducible gene 5/viperin is expressed in atherosclerosis and regulated by proinflammatory agents. Arterioscler Thromb Vasc Biol. 2005; 25: el13116.

9) Reinhardt B, Mertens T, Mayr-Beyrle U, et al. HCMV infection of human vascular smooth muscle cells leads to enhanced expression of functionally intact PDGF beta-receptor. Cardiovasc Res. 2005; 67: 151-160.

10) Bruggeman CA. Does Cytomegalovirus Play a Role in Atherosclerosis? Herpes. 2000; 7: 51-54.

11) Kruger RM, Shannon WD, Arens $M Q$, et al. The impact of ganciclovir-resistant cytomegalovirus infection after lung transplantation. Transplantation. 1999; 68: 12721279.

12) Jabs DA, Enger C, Forman M, et al. Incidence of foscarnet resistance and cidofovir resistance in patients treated for cytomegalovirus retinitis. The Cytomegalovirus Retinitis and Viral Resistance Study Group. Antimicrob Agents Chemother. 1998; 42: 22402244.

13) Sakai A, Watanabe K, Koketsu M, et al. Anti-human cytomegalovirus activity of constituents from Sasa albo-marginata (Kumazasa in Japan). Antivir Chem Chemother. 2008; 19: 125-132.

14) Akuzawa K, Yamada R, Li Z, et al. Inhibitory effects of tricin derivative from Sasa albo-marginata on replication of human cytomegalovirus. Antiviral Res. 2011; 91: 296303.

15) Shibata M, Kubo K, Onoda M. Pharmacological studies on bamboo grass. (2) Central depressant and antitoxic actions of a water-soluble fraction (folin) extracted from Sasa albomarginata Makino et Shibata. Nippon Yakurigaku Zasshi. 1976; 72: 531-541.

16) Shibata M, Yamatake Y, Sakamoto M,et al. Pharmacological studies on bamboo grass (1). Acute toxicity and anti-inflammatory and antiulcerogenic activities of water-soluble fraction(Folin) extracted from Sasa albomarginata Makino et Shibata. Nippon Yakurigaku Zasshi. 1975; 71: 481-490.

17) Kuboyama N, Fujii A, Tamura T. Antitumor activities of bamboo leaf extracts (BLE) and its lignin (BLL). Nippon Yakurigaku Zasshi. 1981; 77: 579-596.

18) Murayama T, Li Y, Takahashi T, et al. Anti-cytomegalovirus effects of tricin are dependent on CXCL11. Microbes Infect. 2012; 14: 1086-1092. 
19) Yamada R, Suda H, Sadanari H, et al. Synergistic effects by combination of ganciclovir and tricin on human cytomegalovirus replication in vitro. Antiviral Res. 2016; 125: 79-83.

20) Xu LL, Warren MK, Rose WL, et al. Human recombinant monocyte chemotactic protein and other C-C chemokines bind and induce directional migration of dendritic cells in vitro. J Leukoc Biol. 1996; 60: 365371.

21) Carr MW, Roth SJ, Luther E, et al. Monocyte chemoattractant protein 1 acts as a T-lymphocyte chemoattractant. Proc Natl Acad Sci USA. 1994; 91: 3652-3656.

22) Murayama T, Kikuchi M, Miita T, et al. Human cytomegalovirus replication supported by virus-induced activation of CCL2-CCR2 interactions. Biochem Biophys Res Commun. 2014; 453: 321-325.

23) Furukawa T, Fioretti A, Plotkin S. Growth characteristics of cytomegalovirus in human fibroblasts with demonstration of protein synthesis early in viral replication. J Virol. 1973; 11: 991-997.

24) Wentworth BB, French L. Plaque assay of cytomegalovirus strains of human origin. Proc Soc Exp Biol Med. 1970; 135: 253-258.

25) Dozono H, Ikeda K, Onishi T. Effectiveness of Ge-132 to relieve pain and smooth home care administration for the terminal cancer patient. Gan To Kagaku Ryoho. 1996; 23 Suppl 3: 291-295.

26) Yokochi S, Hashimoto H, Ishiwata $Y$, et al. An antiinflammatory drug, propagermanium, may target GPIanchored proteins associated with an MCP-1 receptor, CCR2. J Interferon Cytokine Res. 2001; 21: 389-398.

27) Kito K, Morishita K, Nishida K. MCP-1 receptor binding affinity is up-regulated by pre-stimulation with MCP-1 in an actin polymerization-dependent manner. J Leukoc Biol. 2001; 69: 666-674.
28) Lee EY, Chung CH, Khoury CC, et al. The monocyte chemoattractant protein-1/CCR2 loop, inducible by TGF-beta, increases podocyte motility and albumin permeability. Am J Physiol Renal Physiol. 2009; 297: F85-94.

29) Yazawa K, Kurokawa M, Obuchi M, et al. Anti-influenza virus activity of tricin, 4',5,7-trihydroxy-3',5'dimethoxyflavone. Antivir Chem Chemother. 2011; 22: $1-11$.

30) Li H, Dummer JS, Estes WR, et al. Measurement of human cytomegalovirus loads by quantitative real-time PCR for monitoring clinical intervention in transplant recipients. J Clin Microbiol. 2003; 41: 187-191.

31) Hamilton ST, Scott GM, Naing Z, et al. Human cytomegalovirus directly modulates expression of chemokine CCL2 (MCP-1) during viral replication. J Gen Virol. 2013; 94: 2495-2503.

32) Bodaghi B, Jones TR, Zipeto D, et al. Chemokine sequestration by viral chemoreceptors as a novel viral escape strategy: withdrawal of chemokines from the environment of cytomegalovirus-infected cells. J Exp Med. 1998; 188: 855-866.

33) Petrik DT, Schmitt KP, Stinski MF. Inhibition of cellular DNA synthesis by the human cytomegalovirus IE86 protein is necessary for efficient virus replication. $\mathrm{J}$ Virol. 2006; 80: 3872-3883.

34) Meucci O, Fatatis A, Simen AA, et al. Chemokines regulate hippocampal neuronal signaling and gp 120 neurotoxicity. Proc Natl Acad Sci USA. 1998; 95: 1450014505.

35) Wu L, Zhou Y, Zhou Z, et al. Nicotine induces the production of IL-1beta and IL-8 via the alpha7 nAChR/ NF-kappaB pathway in human periodontal ligament cells: an in vitro study. Cell Physiol Biochem. 2014; 34: 423-431. 


\author{
ABSTRACT \\ Inhibition of Human Cytomegalovirus Replication by Compound Derivative \\ from Sasa albomarginata is Associated with CCL2/CCR2 Interaction \\ Yumiko AKAI ${ }^{1}$, Kaori MOGI ${ }^{1}$, Hidetaka SADANARI ${ }^{1}$, Masaya TAKEMOTO $^{1}$, Keiko MATSUBARA ${ }^{1}$, \\ Tohru DAIKOKU ${ }^{1}$, Yuuzo TSUCHIDA², Daisuke SAKURAI ${ }^{2}$, Tsugiya MURAYAMA ${ }^{1, *}$ \\ ${ }^{1}$ Department of Microbiology and Immunology, Faculty of Pharmaceutical Sciences, Hokuriku University \\ ${ }^{2}$ Hououdou Co., Ltd.
}

\begin{abstract}
We previously reported that treatment with tricin (4',5,7-trihydroxy-3',5'-dimethoxyflavone) after human cytomegalovirus (HCMV) infection significantly suppressed both infectious virus production and HCMV replication in human embryonic lung fibroblast (HEL) cells. Moreover, we recently revealed that HCMV infection can increase the expression of CC-motif ligand 2 (CCL2/MCP-1) and CCR2, a specific receptor for CCL2, which can enhance HCMV infection and replication, in turn. In this study, we examined whether CCL2 and/or CCR2 are involved in the anti-HCMV effects of tricin in HEL cells. Exposure of fibroblasts to tricin inhibited infectious HCMV production, with concomitant decreases in CCL2 and CCR2 transcript levels and CCL2 protein levels in a dose-dependent manner. Propagermanium, an inhibitor of CCR2 function, has also been shown to inhibit infectious HCMV production with concomitant decreases in CCL2 protein levels. We further observed that tricin and propagermanium reduced mRNA expression of HCMV immediate early gene and DNA polymerase in a dose-dependent manner. These results suggest that tricin is a novel anti-inflammatory compound with potential anti-HCMV activity, and CCL2/CCR2 interactions are associated with HCMV replication.
\end{abstract}

Key words: Human cytomegalovirus, Tricin, CCL2, CCR2, Propagermanium, Anti-inflammatory compound 
